\title{
Role of sinking and ascent during sexual reproduction in the marine diatom Ditylum brightwellii
}

\author{
Anya Waite ${ }^{1}$, Paul J. Harrison ${ }^{2}$ \\ ${ }^{1}$ Department of Oceanography, University of British Columbia, Vancouver, British Columbia, Canada V6T 1Z4 \\ ${ }^{2}$ Departments of Botany and Oceanography, University of British Columbia, Vancouver, British Columbia, Canada V6T 1 Z4
}

\begin{abstract}
The induction of sexuality was documented during a fall bloom of the marine diatom Ditylum brightwellii. Large numbers of cells bearing male and female gametes and some resting spores occurred simultaneously. When laboratory cultures of $D$. brightwellii became sexual after nitrogen starvation, sinking rates of cells in different stages of sexual reproduction were measured for the first time. Cell sinking rates increased from a low of $0.02 \mathrm{~m} \mathrm{~d}^{-1}$ for asexual cells to a high of $1.4 \mathrm{~m} \mathrm{~d}^{-1}$ for early post-auxospore cells. These high sinking rates decreased rapidly, and within a day after postauxospore formation, a measurable fraction (up to $90 \%$ ) of the post-auxospore cells had substantial ascent rates (up to $3 \mathrm{~m} \mathrm{~d}^{-1}$ upwards). Physiologically stressed cells might therefore sink from the photic zone during sexual reproduction, and then recolonize the surface as new post-auxospore cells. In a temporally and spatially patchy environment, the increase in sinking rate followed by the development of an ascending fraction of a population could increase the recolonization potential of a species. Ultimately, sinking and ascent patterns during sexual reproduction could influence the evolutionary balance of costs and benefits of sex in diatoms.
\end{abstract}

\section{INTRODUCTION}

In general, the creation of genetic diversity remains the primary rationalization for the evolutionary maintenance of sexuality over reproductively more efficient asexual reproduction (Williams 1975). Intraspecific genetic variation within species of marine phytoplankton can be greater than genetic differences between entirely different species of terrestrial plants (Wood 1988). To what extent might the oceanic environment select for this high genetic diversity?

The environment in which phytoplankton (both aquatic and oceanic) grow is highly variable in time and space. Diurnal and seasonal changes in mixed layer depth (e.g. Woods \& Barkmann 1986), coupled with tidal mixing (Pingree et al. 1978) and wind mixing (Therriault \& Platt 1981) cause periodic fluctuations in stability and temperature of the ocean surface, changing irradiance, nutrient availability (and thus maximum growth rate), on a wide variety of time scales. In addition, sporadic amplification of phytoplankton patch growth through non-linear interactions with physical processes at a variety of time scales (Denman \& Powell 1984) create either 'noisy' (random) phytoplankton distributions or 'patchy' (mosaic-like) distributions, depending on the physical regime (Bennett \& Denman 1985). Patch survival, in turn, may depend on the patch reaching a critical size (ca $1 \mathrm{~km}$; Kierstead \& Slobodkin 1953). For instance, non-linear interactions of phytoplankton and grazers can make patches larger or smaller than expected from growth alone, and can even prevent their patch dispersal through turbulent lateral diffusion (Steele 1974). For the purpose of the following discussion, a 'patch' suitable for growth means a relatively small $(1 \mathrm{~m}$ to $1 \mathrm{~km})$ physical area where irradiance and nutrient concentrations are sufficient for the initiation of growth of a given species (essentially the patch, sensu Hutchinson 1961). This physical 'patch' must then persist in time long enough for phytoplankton to respond physiologically to the favourable conditions, and divide (at least once).

Once a species clone begins to grow in a patch to which it is genetically suited, diffusion of cells out of the patch becomes detrimental to population growth. 
The fact that many diatoms form chains, for instance suggests that there may be adaptive value to keeping daughter cells within a growing population. Brand (1982) has evidence that turbulent diffusion, sweeping organisms out of a patch, can indeed serve as an important loss to a growing population. Similarly, one might expect that under suitable growth conditions, sinking processes too would constitute a loss.

However, because in the longer term all patches are ephemeral, the need to maintain growing populations in suitable surface 'patches' must be balanced by the eventual distribution of cells to new future 'patches'. Therefore, cells must balance potential growth losses through biomass diffusion and sinking against the benefits of dispersal by these same methods

In a highly unpredictable and patchy environment in both time and space, the maintenance of genetic diversity within a species may be especially important for successful dispersal. Maintenance of diversity may allow different clones of a single species of diatom to bloom under a variety of different environmental conditions (different types of 'patches'). Such genetic variability has already been documented for Skeletonema costatum (Gallagher 1983) and Thalassiosira aestivalis/pacifica (Roelofs 1983). Both these species are known to dominate coastal diatom blooms. If sexual reproduction is the primary source of genetic variation in marine phytoplankton, then periodic sexual induction may play an important role increasing the success of 'patch' colonization.

However, unicellular clonal populations such as those of marine diatoms are especially vulnerable to the reductions in effective growth rate necessitated by sexual induction (Lewis 1983) since their growth rate is a direct reflection of their fitness (Wood 1988). Sexual reproduction decreases the fitness of organisms in the short term. Specifically, the costs of sex (meaning basically the temporary loss of the ability to produce offspring) are referred to as the cellular mechanical costs' due to the interruption of normal vegetative growth, the 'cost of meiosis' which refers to the cost of producing one large or many small gametes, the 'cost of fertilization' which refers to the time and energy of finding a mate, and finally, the 'cost of recombination', which refers to the potential of completely losing the parent genotype if the entire population recombines. These costs must be mitigated or compensated for if sexuality is to be retained over evolutionary time. Diatoms must have ways to minimize these costs. For instance, if sex accurs only when growth rates are obligately low (through nutrient limitation (Davis et al. 1973, Drebes 1966, 1977), sudden increases in growth irradiance (Drebes 1966) or decreases in temperature (Drebes 1977)], the reproductive losses are minimized
Longer-term compensation for the short-term costs of sexuality may include an increase in growth rate after sexual reproduction (Costello \& Chisholm 1981), increased genetic diversity, and the restoration of larger cell width supposedly necessary after a long series of vegetative divisions over which the cells become narrower.

How and when sexual cells sink from the surface or ascend to it could influence the balance of costs and benefits of sex in diatoms. Whether recombined cells leave the parent population or remain at the surface must influence the eventual distribution of a species. Although one study documented increased sinking rates after sexual reproduction due to the increase in the average diameter of recombined cells (Smayda \& Boleyn 1966), the sinking dynamics of sexual cells have not been documented.

The objective of this work was to measure, for the first time, changes in the sinking rate (and ascent rate) of cells undergoing sexual reproduction in Ditylum brightwellii. When $D$. brightwellii was subjected to repeated nitrogen starvation, after an increase in growth irradiance, the formation of sexual cells was induced. The sinking and ascent rates of asexual cells, early sexual cells, gametes, zygotes, and postauxospore cells were measured, documenting an increase in sinking rate as sexual induction progressed. A natural bloom of $D$. brightwellii was observed at Jericho Beach near Vancouver, B.C., Canada, in which a fraction of the population became sexual.

\section{MATERIALS AND METHODS}

Field measurements. As part of a regular plankton monitoring program by Prof. F. J. R. Taylor and coworkers, Dept of Oceanography, University of British Columbia, the phytoplankton assemblage in the top $3 \mathrm{~m}$ off the pier at Jericho Beach, Vancouver, was sampled weekly between 1989 and 1991 (except for winter sampling, which was monthly). Jericho Beach lies on the southern shore of Burrard Inlet, about $5 \mathrm{~km}$ east of the opening of Burrard Inlet into the southern Strait of Georgia, a large inland sea between Vancouver Island and the mainland of British Columbia. The southern shore of Burrard Inlet between Jericho Beach and the inlet mouth is dominated by the shallow mudflats known as Spanish Banks. The depth near Jericho pier is $4 \mathrm{~m}$ at high tide, and the area can be stratified by the freshwater plume of the Fraser River when winds and tides force the river plume northward.

A $30 \mu \mathrm{m}$ mesh plankton net was lowered of the pier at high tide to just above the bottom and hauled vertically upward. Usually a sweep along the surface was also performed as part of the same net haul. A Niskin 
bottle was used to obtain a quantitative surface sample for temperature (measured immediately), and salinity (measured with a refractometer upon return to the laboratory). Duplicate sub-samples from this bottle cast for plankton analysis were immediately preserved with Lugols iodine solution and were observed under a Zeiss IM inverted microscope and photographed with the attatched Zeiss camera with Kodak TMax 100 film at 10,20 and $40 \times$ magnification. A $10 \mathrm{ml}$ subsample of each surface sample was settled for full plankton enumeration. Samples from the net haul were settled for species identification as presence/absence or dominance (>50\%) only.

Laboratory experiments. Two $50 \mathrm{ml}$ batch cultures of Ditylum brightwellii were inoculated from the Northeast Pacific Culture Collection (NEPCC \# 8a), where it had been growing at 7 to $10 \mu \mathrm{mol}$ photons $\mathrm{m}^{-2}$ $\mathrm{s}^{-1}$ (under light limitation and potentially also nutrient limitation) in enriched natural seawater. They were placed under continuous saturating irradiance (ca 110 umol photons $\mathrm{m}^{-2} \mathrm{~s}^{-1}$ ) in artificial seawater (ESAW; Harrison et al. 1980) with modifications as in Waite et al. (1992). All nutrients were initially saturating except for nitrate, which was ca $10 \mu \mathrm{mol} \mathrm{l}^{-1}$. Cultures were kept at $17{ }^{\circ} \mathrm{C}$ and stirred with a teflon-coated stir bar at ca $80 \mathrm{rpm}$. These $50 \mathrm{ml}$ cultures were allowed to grow until nitrate became limiting and exponential growth slowed (ca 4 d after inoculation). Cultures were left to become nitrogen deplete for another $3 \mathrm{~d}$, and then a saturating concentration of $\mathrm{NaNO}_{3}\left(>500 \mu \mathrm{mol} \mathrm{l}^{-1}\right)$ was added. Exponential growth reoccurred within $24 \mathrm{~h}$. After $24 \mathrm{~h}$, cells were transferred to $1 \mathrm{l}$ flasks and grown for a further $4 \mathrm{~d}$ in N-saturated medium. Each $1 \mathrm{l}$ flask was then inoculated into a 12 l low $\mathrm{N}$ batch culture such that the new $\mathrm{NO}_{3}$ concentration was again about $10 \mu \mathrm{mol} \mathrm{l}^{-1}$. The two $12 \mathrm{l}$ cultures were monitored for $5 \mathrm{~d}$, until low growth rates and high sinking rates were observed, indicating the cultures were physiologically stressed. Cultures were then examined microscopically, and sexual cells were observed. The first observation of sexual cells was termed the beginning of the time series, $t=0$. At this time, a 2 l subsample was removed from each $\mathrm{N}$-deplete $12 \mathrm{l}$ culture, and spiked with saturating $\mathrm{NaNO}_{3}\left(>500 \mu \mathrm{mol} \mathrm{l}{ }^{-1}\right.$ ) to form 2 new $\mathrm{N}$-replete cultures. Subsequently, all 4 cultures ( 2 with $\mathrm{NO}_{3}$ added, referred to as $\mathrm{N}$-replete $(+\mathrm{N}$ ), and 2 without $\mathrm{NO}_{3}$ added, referred to as $\mathrm{N}$-deplete $(-\mathrm{N})$, were maintained at a saturating irradiance.

$\mathrm{N}$-deplete batch cultures were monitored from time $t=0$ until late scenescence (10 d later). N-replete cultures were maintained in log phase as semi-continuous batch cultures, with a dilution every ca $4 \mathrm{~d}$. The $\mathrm{N}$ replete cultures were monitored until $>90 \%$ of the cells had been sexually induced (40 d later). Smaller subcultures of the $+\mathrm{N}$ cultures were then placed at: (1) $110 \mu \mathrm{mol}$ photons $\mathrm{m}^{-2} \mathrm{~s}^{-1}$; (light-saturated; LS), (2) ca 7 to $10 \mu \mathrm{mol}$ photons $\mathrm{m}^{-2} \mathrm{~s}^{-1}$ (light-limited; LL) and (3) at light-limited irradiance at $4{ }^{\circ} \mathrm{C}$ (LL-cold). These cultures were kept as semi-continuous cultures as above for a further 4 mo to ascertain under which treatment the fraction of sexual cells decreased. Several post-auxospore cells were isolated from cultures which had undergone sexual recombination and used to form new cultures. Growth rates were monitored for several weeks, and cultures were checked microscopically for the presence or absence of sexual cells.

Sinking rates and ascent rates were measured using the SETCOL method (Bienfang 1981) with the calculation modified as in Waite et al. (1992), using cell numbers as the biomass index (rather than chlorophyll). Samples were diluted 1:4 with filtered $3 \% \mathrm{NaCl}$ before counting. All settling trials ran for $3 \mathrm{~h}$, at $17^{\circ} \mathrm{C}$ at $110 \mu \mathrm{mol}$ photons $\mathrm{m}^{-2} \mathrm{~s}^{-1}$.

Cell counts of the top, middle and bottom fractions of the SETCOL column were made first on a Coulter Counter ${ }^{*}$, using the $200 \mu \mathrm{m}$ aperture. Counts of the percent of cells at different sexual stages (Fig. 1) in all fractions were made under the inverted microscope using the Utermöhl method (Utermöhl 1958). The percent composition of the fractions was then multiplied by the total cell number in each fraction to yield an estimate of the numbers of each type of cell in each SETCOL fraction. The sinking rate of each cell type was then calculated separately using the estimate of cell concentration in the different column fractions. In addition, diagrams of each different cell type were traced from photographs of actual cells taken through the microscope (as above).

All sinking rate time series were first checked for temporal trends. Where significant $(p<0.05)$ temporal trends were not found, the mean sinking rate over the time series was calculated. Any comparisons between sinking rates at a given time $t(n=2)$, and time series means $(n=8)$ were made with Student's $t$-test $(p=0.05)$.

Culture growth rates were calculated from the increase in fluorescence over time by regressing the logarithm vs time, and taking the slope of the regression line as one growth rate estimate $(n=1)$. Means and $\mathrm{SD}$ represent the means of several ( $\mathrm{n}=2$ to 4 ) regression slopes.

\section{RESULTS}

\section{The sexual reproduction cycle}

The following brief description of sex in Ditylum brightwellii is included to clarify the terminology used in this section and the discussion (for further details, see Drebes 1977). Cell types and the sexual cycle of $D$. 


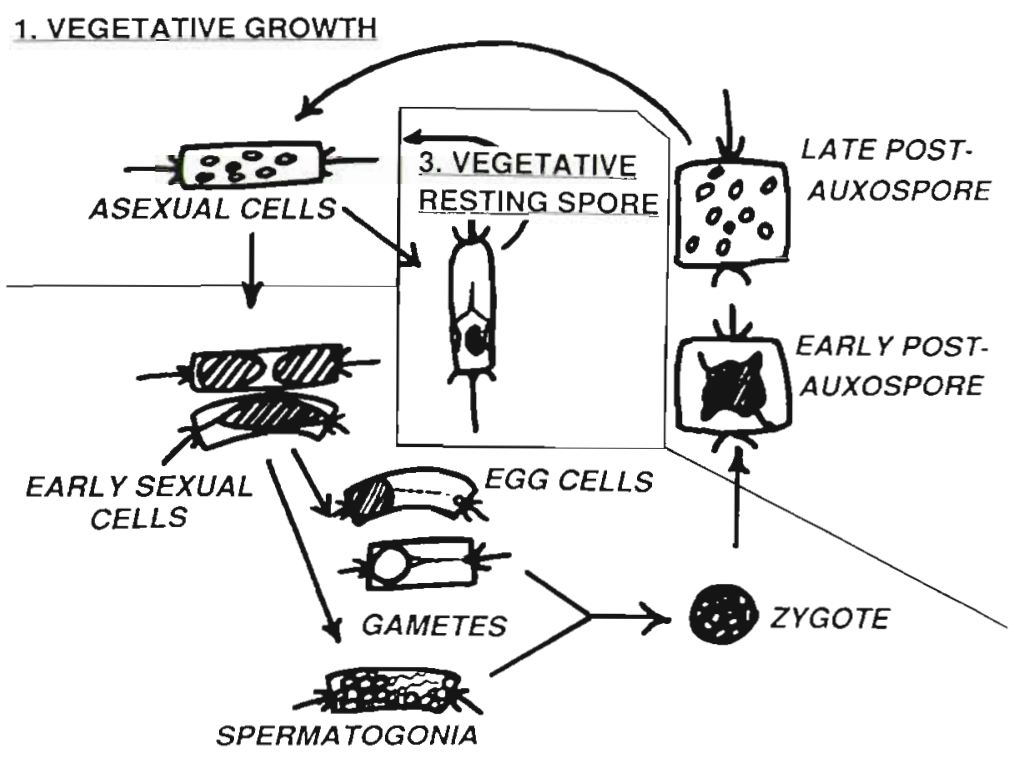

2. SEXUAL REPRODUCTION

Fig. 1. Ditylum brightwellii. Vegetative growth, sexual reproduction and resting spore formation. All cells were traced from photographs of laboratory cultures (see text for details)
The centric diatom sexual cycle involves the differentiation of some cells into cells bearing male and female gametes each through 2 meioses within the parent frustule (here termed gametes). Ditylum brightwellii produces 1 egg cell ${ }^{-1}$ and 32 to 64 male gametes cell ${ }^{-1}$ (Gross 1937. Smayda \& Boleyn 1966). The frustule bends and opens, allowing male gametes to exit between the 2 halves of the frustule, and once male gametes contact an egg cell, they enter the frustule in the same manner. Fertilization involves the fusion of a single male gamete with the egg (zygote), after which a new individual, the auxospore, is formed. The auxospore swells up to $3 \times$ the diameter of the original cell, and then forms a new wider frustule. This new early postauxospore cell is 2 to $3 \times$ the width of the old cell, and initially still has cytoplasm concentrated in the centre of the cell. Late post-auxospore cells have chloroplasts spread throughout the new, larger frustule. brightwellii are illustrated schematically in Fig. 1. Healthy exponentially growing vegetative cells were termed asexual cells. Cells first indicated the onset of sexuality by becoming slightly elongated, curved, darkened and irregular in shape: these were termed early sexual cells.

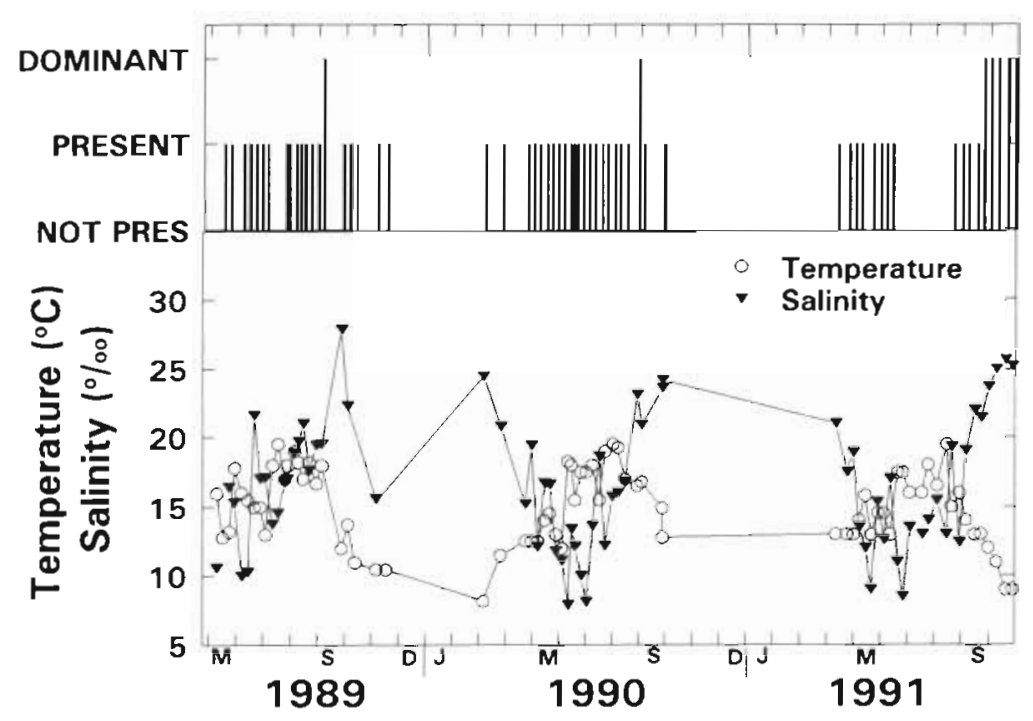

Fig. 2. Ditylum brightwellii. Time series of presence/absence data at Jericho Pier, Vancouver, B.C., between 1989 and 1991 'Dominant' indicates periods when this species formed over $50 \%$ of cell numbers of the net-collected phytoplankton assemblage. Temperature $\left({ }^{\circ} \mathrm{C}\right)$ and salinity $(\%)$ were measured on surface water samples
Field observations

Long term monitoring of the phytoplankton at the Jericho Beach site by Prof. F. J. R. Taylor's laboratory indicated that the site is dominated by diatoms in the spring and fall, with dinoflagellates and other flagellates dominating in the summer months.

Ditylum brightwellii has been observed to bloom briefly at Jericho Pier every fall for the last 3 yr (Fig, 2). In 1991, the fall bloom was delayed due to unusually sunny weather, and did not occur until a storm induced wind mixing in late September. D. brightwellii reached 21300 cells $\mathrm{l}^{-1}$ by October 28, 1991, when sexual cells of this species were clearly visible (Fig. 3). Cells bearing female gametes were present at 100 cells $l^{-1}$ and cells bearing male gametes were present at 600 cells $1^{-1}$, making up ca $3 \%$ of the population. By the November 5 sampling, the population no longer contained a measurable sexual fraction. In addition to sexual cells, numerous resting spores were observed (ca 300 cells $1^{-1}$ ) within the population.

Ditylum brightwellii was also observed to dominate other sites in the Strait of Georgia (Nelson Is, and Cape Mudge) during the delayed 1991 fall diatom bloom. Although this species has been seen to 


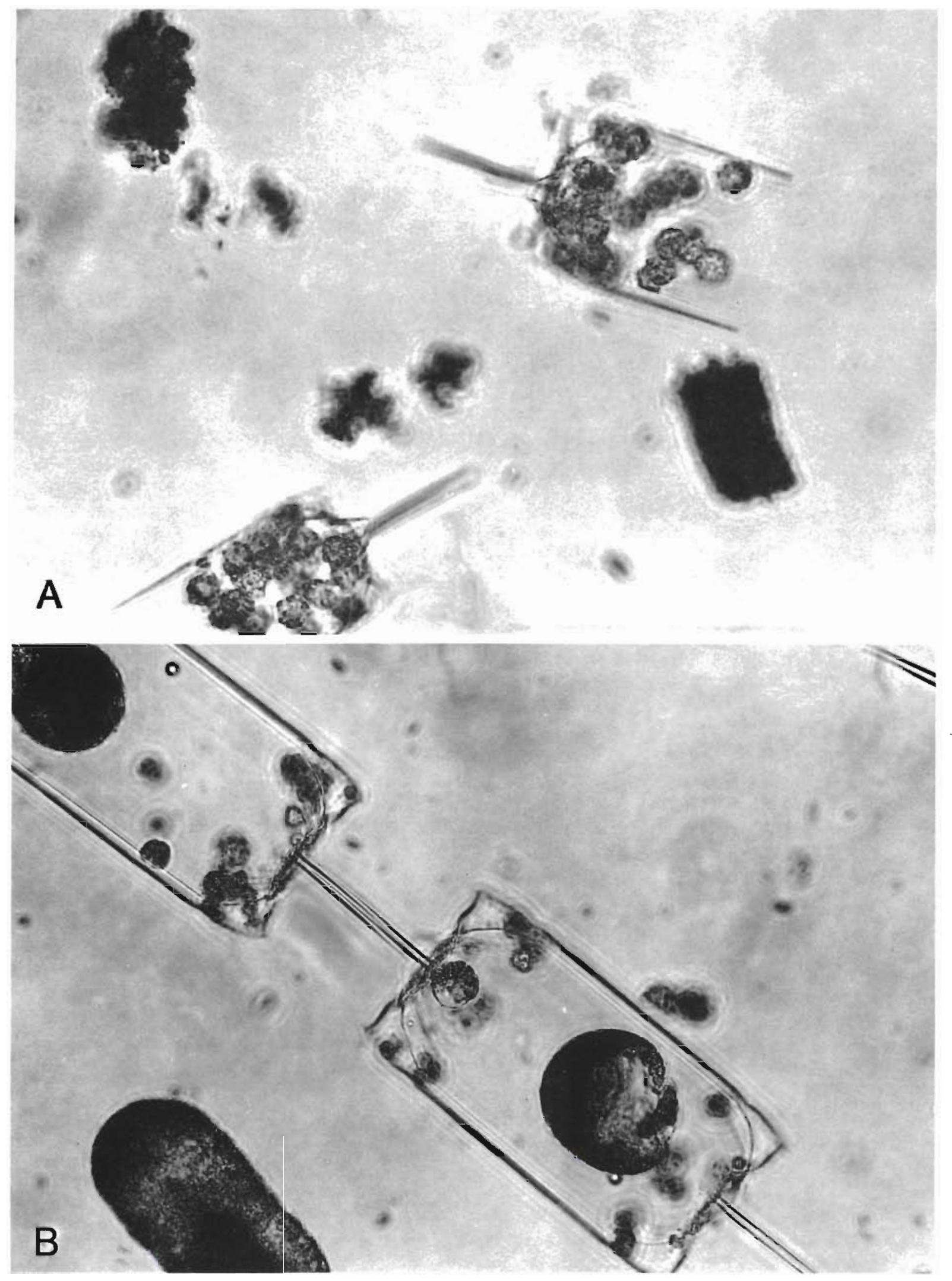

Fig. 3. Ditylum brightwellii. (A) Male gametes and (B) egg cells from surface water samples at Jericho Pier during the fall diatom bloom in October 1991 . Cells are ca $700 \times$ actual size 
bloom in the fall at these other sites in other years, its greater dominance in 1991 was unusual (R. Haigh unpubl.).

\section{Laboratory observations}

The first general indications of sexuality in the Ditylum brightwellii cultures at $t=0$ were that growth rates began to decrease and sinking rates were anomalously high $\left(>0.2 \mathrm{~m} \mathrm{~d}^{-1}\right)$. Once the culture was split into $-\mathrm{N}$ and $+\mathrm{N}$ cultures, the $-\mathrm{N}$ cultures' growth rate decreased rapidly and reached 0 at $t=10 \mathrm{~d}$, while the $+\mathrm{N}$ cultures' growth rates continued to fluctuate and recovered by $t=40$ (at $t=40$, new vegetative cells (post-auxospores) formed most of the biomass; Fig. 4A). Until growth ceased in the $-\mathrm{N}$ cultures, sinking rates in $-\mathrm{N}$ and $+\mathrm{N}$ were similar.

The percent composition of different cell types in the $+N$ and $-N$ cultures quickly diverged (Fig, $4 \mathrm{~A}, \mathrm{~B}$ ). Initially, about $25 \%$ of the cells were asexual in both treatments, and early sexual cells formed almost $75 \%$ of the total, with a few cells having reached the postauxospore stage. In the $+\mathrm{N}$ cultures, the fraction of post-auxospore cells increased over time, and after

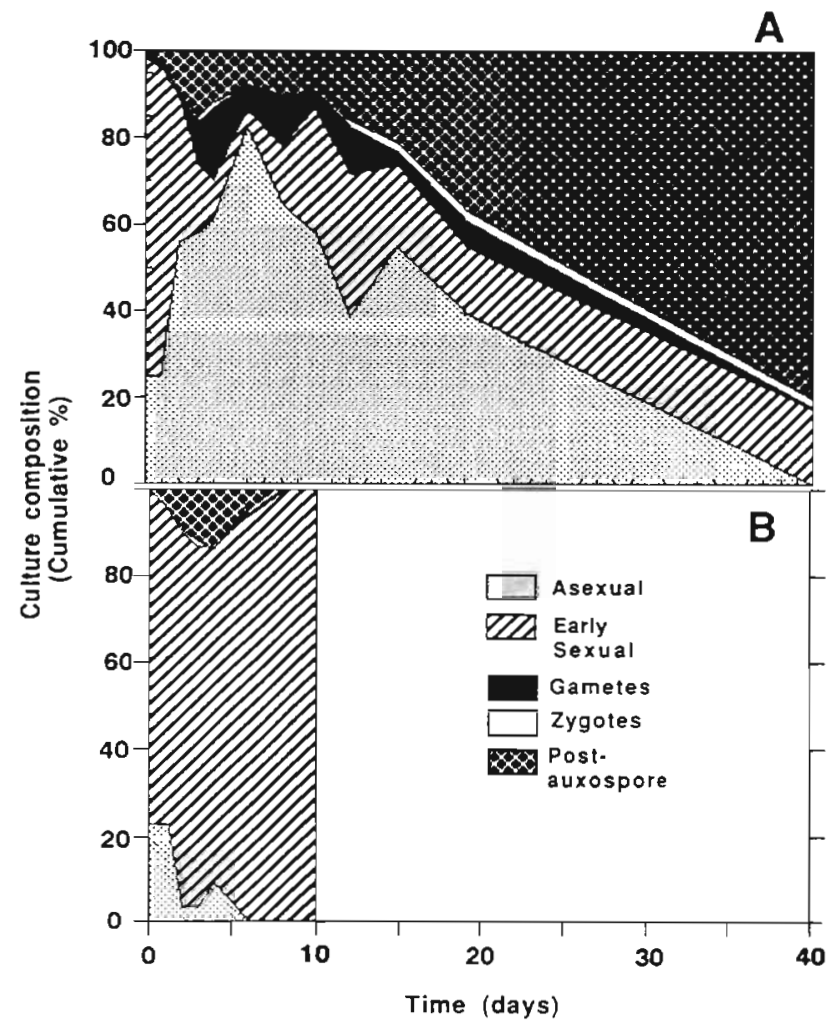

Fig. 4. Ditylum brightwellii. Composition of cell types in cultures in which sexual reproduction occurred over time during the experiment. (A) Cultures kept in fully nutrient-enriched medium $(+N)$. (B) Cultures kept in low nitrate medium $\left(-N_{i}\right.$ ca $\left.0 \mu \mathrm{mol} l^{-1}\right) .-N$ cultures did not survive past $t=10 \mathrm{~d}$

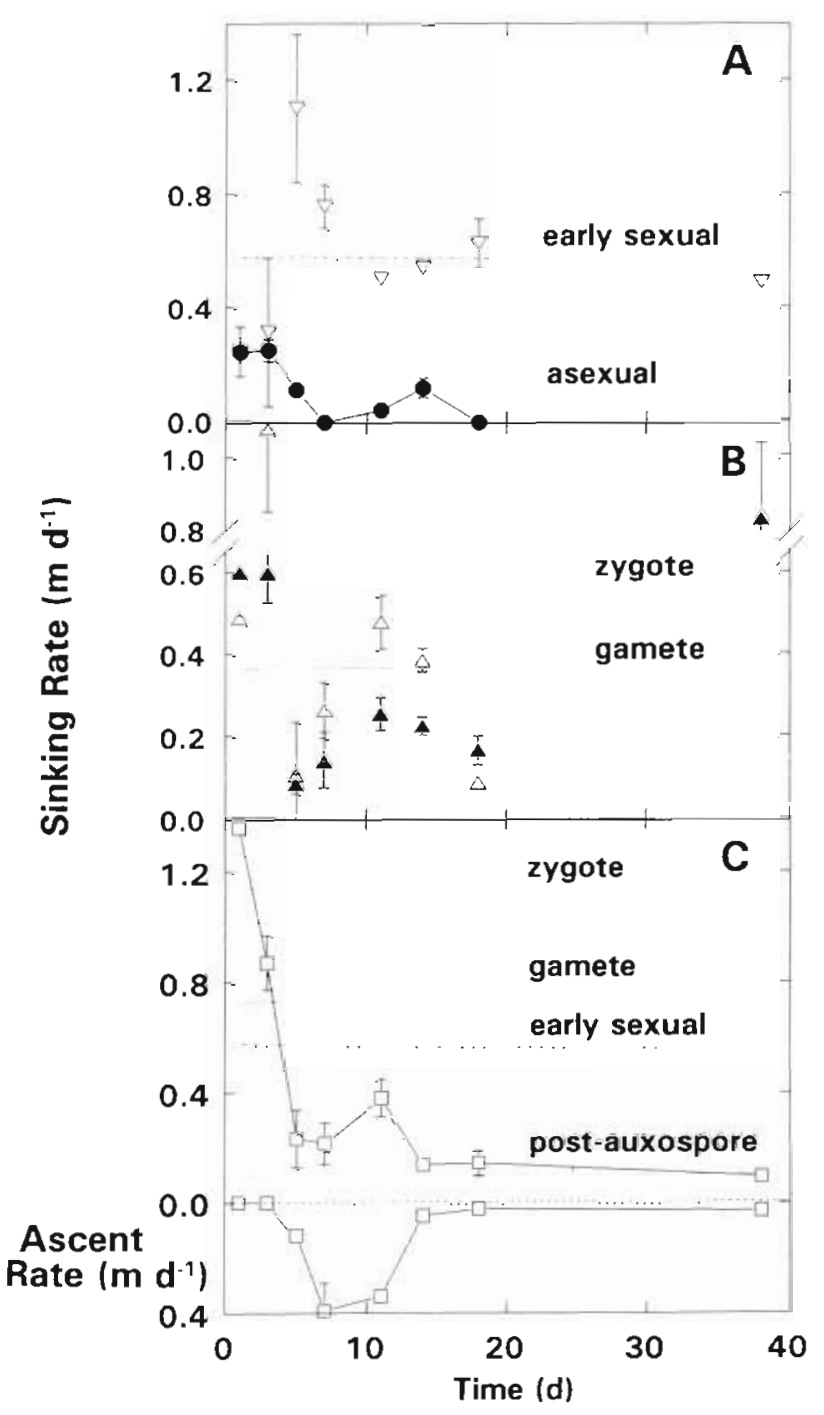

Fig. 5. Ditylum brightwellii. Time series of sinking rates of cells in different stages of sexuality. For sinking rates with no time trend, mean sinking rates are given as dashed or dotted horizontal lines. For sinking rates with time trends, data points are joined. All error bars represent $1 \pm \mathrm{SD}$. (A) Asexual cells $(\bullet)$ and early sexual cells $(\nabla)$. (B) Sexual cells (containing male or female gametes) ( $\mathbf{)}$ ) and zygotes (A). (C) Postauxospore cells $(\square)$ : mean sinking rates and mean ascent rates both shown. Mean sinking for zygotes, gametes and early sexual stages from (A) and (B) are presented here for comparison

$40 \mathrm{~d}$, post-auxospore cells were $>80 \%$ of the biomass (Fig. $4 \mathrm{~A}$ ). In the $-\mathrm{N}$ cultures, after the first $3 \mathrm{~d}$, the fraction of post-auxospore cells declined over time. Gametes were never formed in significant numbers, and most of the culture did not proceed through a complete sexual cycle. Instead, $-\mathrm{N}$ cells were arrested at the early sexual stage (Fig. 4B).

Too few asexual cells survived in the $-N$ cultures to determine their sinking rate. The sinking rates 
of asexual cells $(+N)$ showed a significant decrease with time after the addition of nitrogen at $t=0 \mathrm{~d}$. By $t=20 \mathrm{~d}$, asexual cells had normal, low sinking rates (ca $0.002 \mathrm{~m} \mathrm{~d}^{-1}$; Fig. 5A). There was no significant temporal trend in the sinking rates of early sexual cells, gamete-bearing cells, or zygotes, and they were highly variable (Figs. 5A, B). The temporal mean from $t=0$ to $t=40 \mathrm{~d}$ is given as a horizontal line whenever no temporal trend was found. Zygotes sank significantly faster than asexual cells, but no significant differences were found between the temporal means of early sexual cells, gametes, and zygotes. Ascending cells were not consistently observed for any of these cell types.

Post-auxospore cells showed a decrease in sinking rate over time (Fig. 5C). In addition, a fraction (varying between 10 and $90 \%$ ) of the post-auxospore cells began to ascend within $3 \mathrm{~d}$ of $\mathrm{N}$ addition, actually achieving substantial floating rates (up to $0.4 \mathrm{~m} \mathrm{~d}^{-1}$ ). The mean sinking rates and mean ascension rates defined an average range of sinking rates for post-auxospore cells (hatched area; Fig. 6) which decreased over time.

In order to visualize the sinking rate progression of cells undergoing sexuality, mean sinking rates of the early sexual cells were plotted as a 'time series', beginning with the initial sinking rates of the asexual cells to the high sinking rates of the zygotes and early postauxospore cells. The actual time series of the sinking rates of the post-auxospore cells was then added as they progressed through the sexual event and finally approached 'normal' sinking rates once more (Fig. 6).

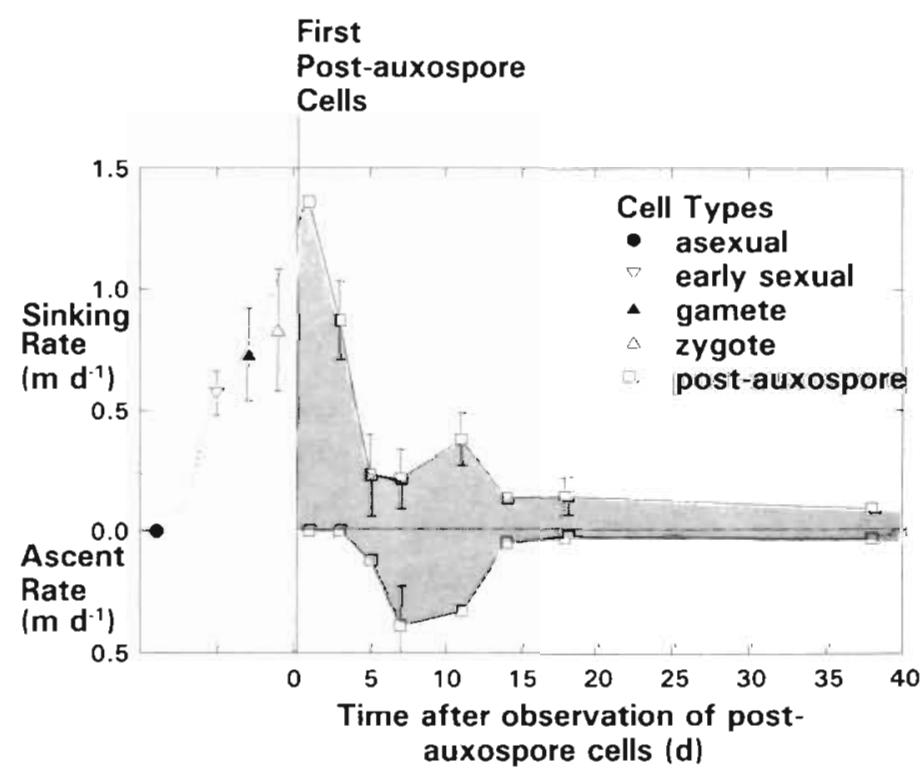

Fig. 6. Ditylum brightwellii. Sinking rate and ascent rate time series of cells during a sexual reproduction cycle. Hatched area represents average sinking/ascent rate range
At $17^{\circ} \mathrm{C}$, post-auxospore cells continued to be produced and were prevalent (ca $25 \%$ sexual cells) in light-saturated (LS) cultures for the 4 mo during which they were observed. The wide diameter cells decreased in width quickly (within $3 \mathrm{wk}$ ), and growth rates remained high (ca $1 \mathrm{~d}^{-1}$ ). LL (light-limited) cells, grown at $0.4 \mathrm{~d}^{-1}$, also decreased their cell width, but were free of gametes, zygotes and post-auxospore cells after 4 mo (only a few early sexual cells were observed in these cultures). Generally, LL cultures looked healthier than LS cultures. LL cultures kept at $4{ }^{\circ} \mathrm{C}$ (LLcold) were intermediate. They had more (>40\%) asexual cells than LS cultures but maintained a significant fraction of early sexual cells, gametes and zygotes, in contrast to the $17^{\circ} \mathrm{C}$ LL cultures which had none at the end of the 4 mo period

\section{DISCUSSION}

\section{Physiological implications}

Since cells in this study went through both a sudden increase in irradiance and low nutrient stress before sexuality was observed, it is unclear which was the principal factor inducing sexuality. Ditylum brightwellii has been grown asexually for several months at the same irradiances at which sexuality was induced (Waite et al. 1992). Therefore, light alone is unlikely to be the critical factor. A combination of both the transition in light intensity and nutrient stress may have been the trigger for sexuality.

Because the $+\mathrm{N}$ cultures were actively growing, the continued presence of a significant fraction of sexual cells in the cultures over time must have indicated continual production of sexual cells, not simply the arrestation of sexual reproduction in the middle of the cycle. Sandgren's (1981) work on the chrysophyte Dinobryon cylindricum suggested that a constant low level of sexuality $(<0.01 \%$ cells induced) might evolve as a general response to a constantly fluctuating environment, while more intense sexual events ( $>10 \%$ cells induced) might occur in response to more severe cases of nutrient stress. Alternatively, the cells in the present study might also have been in an inducible stage in culture over a longer cycle (such as that suggested by Round 1972 and Lewis 1984).

However, it is clear that once sexuality is induced, it is irreversible in the short term, especially under saturating irradiances and saturating nutrient concentrations. In fact, in the present study, wide, post-auxospore cells were even 
observed forming gametes, undergoing a second sexual event in the same culture. This unusual observation suggests that there may have been some specific chemical messenger (or erogen; Machlis 1972) causing the continued induction of sexuality in the cultures once the conditions initially inducing it were no longer present. Sandgren (1981) observed that in the chrysophyte Dinobryon cylindricum, a compound was released continuously into the medium by egg cells to induce male gamete formation. Starr \& Jaenicke (1974) found an erogen formed by male cells of Volvox carteri which induced the formation of sexual embryos. In culture, the cells would remain trapped with any cell exudates, and sexuality might be induced repeatedly. The fact that sexuality ceased at lower irradiances suggests that if an erogen is produced, its production may be light dependent. Alternatively, cells growing slowly under light limitation might simply produce less erogen, so the erogen may nover have reached the threshold level necessary to induce the cultures. The ecological implications of erogen production are discussed below.

In this study, nitrate was necessary for gamete formation in Ditylum brightwellii. Therefore, gamete formation must demand a greater nitrogen supply than is available intracellularly in a pre-sexual, vegetative cell. This suggests that if sexuality were initiated through surface nitrogen depletion during a bloom, for instance, increases in sinking rate would be essential to allow cells access to nutrients at depth and complete the sexual process. Sinking rate changes might thus be a necessary part of a larger scale ecological response to stressful conditions at the ocean surface.

The physiological reasons for sinking rate increases during sexual induction may be 2 -fold. Firstly, the disappearance of cell vacuoles during the formation of gametes may preclude the control of intracellular density through ionic pumping, the probable mechanism for sinking control in this species (Anderson \& Sweeny 1978). Secondly, even if vacuoles were present during the sexual process, the energetic demands of sexuality might sequester cell energy needed for sinking control (Waite et al. 1992). The fact that post-auxospore cells did not have reduced sinking rates until after the dispersal of cell cytoplasm from the center of the cell suggests that sinking rate control was not possible until vacuoles had reformed.

\section{Ecological implications}

As outlined earlier, because growth rate is generally equivalent to evolutionary fitness for unicellular organisms (Wood 1988), the costs of abandoning asexual growth in favour of sexual reproduction are especially high in these organisms. The purpose of the following discussion is primarily to point out the potentially critical role of changes in sinking rate in modifying the selective pressures on diatoms. Such a discussion must remain speculative, since little is known about the evolutionary role of sexuality in oceanic unicellular eukaryotes. It may, however, suggest useful avenues of future investigation.

If sex occurs in nature as it did in this study for Ditylum brightwellii, the sexual process would quickly effect a vertical partitioning of a population into sinking and non-sinking fractions. Sexual cells sinking more rapidly than asexual cells would become physically isolated, forming a new genetically recombined population at depth, while the surviving asexual population could remain higher in the water column. If an erogen were produced by sexual cells for sexual induction of the asexual population, the physical separation of sexual and asexual fractions of a population would be the only way to limit the sexual event to a fraction of the population. This would be critical in minimizing the high 'cost of recombination' (i.e. the loss of a fit parental genotype) (Stearns 1987). In addition, it could limit the interruption of mitosis, or the 'cellular-mechanical cost' of sex, to a small fraction of the population. This would be important in unicellular eucaryotes, where cellular-mechanical costs of sex are especially high (Lewis 1987).

In a dilute medium, the production of an erogen as discussed above may also be important for minimizing the high 'cost of fertilization' (Stearns 1987). After the formation of post-auxospore cells, however, an erogen would become a liability, inducing recombination in already recombined cells (as observed in this study) and delaying the critical resumption of asexual growth described by Lewis (1983). Erogen production might decrease the 'cost of fertilization', but without sinking rate changes, erogen production would increase both the 'cellular-mechanical cost' and the 'cost of recombination' to sexual diatoms

Sinking rate changes after induction and vertical partitioning of the population would cause any erogen to be rapidly diluted. A sexual event in a population might therefore have its time scale set by the sinking rates of sexual cells, and there could be strong selection for sinking rate increases. After the formation of post-auxospore cells, the existence of a wide range of sinking rates, and the formation of an ascending fraction, would allow a second vertical partitioning of the population, and possible recolonization of the photic zone by ascending cells. In Ditylum brightwellii, substantial ascent rates have only been observed in wide, post-auxospore cells. Generally, the ability for diatoms to ascend increases with cell size (Villareal 1988). Cell size changes observed in this study did not seem to follow the hypothesis of gradual cell width 
reduction over time in this study. Instead, there was a rapid period of cell-width decline followed by maintenance of the original, asexual cell width. One might speculate that the transient cell size enlargement observed in this study may be an adaptation allowing post-sexual flotation of recombined cells. This would effect the second partitioning event in a sexual population, and thus minimize both the risk of lengthening the time of sexuality, and the risk of losing a fit parental genotype.

Finally, the increase in sinking rates and in sinking rate range could increase cell-cell contact rates. This increase in contact rates might help speed aggregation of cells into clumps, further increasing contact rates, and further increasing sinking rates (see Jackson 1990). If the environment were shallow enough to allow cells to reach the bottom, cells accumulating there would have a still greater chance of encountering a mate.

Overall, the effect of sinking rate changes during a sexual event would be: (1) to remove the stressed population rapidly from the photic zone, (2) to allow completion of the sexual process through increased nutrient availability, (3) to cause the formation of a new, recombined population at depth, and (4) to allow recolonization of the upper water layers by enlarged acending cells. While asexual cells can affect factor (1), factors (2) to (4) would occur possibly only through sexuality. Sexuality, coupled with its accompanying sinking rate and ascent rate changes, may have a special role in diatoms, as part of a diatom's large scale physiological response to stress as well as a seeding mechanism.

There is a growing awareness of clonal diversity in marine phytoplankton (Brand et al. 1981, Brand 1982, Krawiec 1982). The observations in this study would be consistent with the assertion by Brand (1982) that genetic recombination is an important mechanism for the expansion of a species' biogeographic range in the ocean. Further study on the diatoms' genetic diversity in relation to their 'patch'-type preference would significantly advance understanding of diatom evolution. For instance, measuring the frequency of polymorphisms of critical enzymes governing light-harvesting, carbon fixation, nutrient uptake and temperature tolerances might yield greater understanding of the difference between the phenotypic plasticity (as measured in nutrient- and photo-adaptation experiments) and true genetic diversity.

Acknowledgements. This research was supported by a grant from the Natural Sciences and Engineering Research Council of Canada. We thank R. Haigh and F. J. R. Taylor for use of their time series data from Jericho Pier, and F. J. R. Taylor for helpful discussions. A. Waite was supported by a NSERC post-graduate scholarship and a U.B.C. University Graduate Fellowship.

\section{LITERATURE CITED}

Anderson, L., Sweeney, B. (1978). Role of inorganic ions in controlling sedimentation rate of a marine centric diatom Ditylum brightwellii. J. Phycol. 14: 204-214

Bennett A. F., Denman, K. L. (1985). Phytoplankton patchiness: inferences from particle statistics. J. mar. Res. 43: 307-355

Bienfang, P. K. (1981). SETCOL - A technologically simple and reliable method for measuring phytoplankton sinking rates. Can. J. Fish. Aquat. Sci. 38: 1289-1294

Brand, L. (1982). Genetic variabiliity and spatial patterns of genetic differentiation in the reproductive rates of the marine coccolithophores Emiliania huxleyi and Gephyrocapsa oceanica. Limnol. Oceanogr. 27: 236-245

Brand, L., Murphy, L. S., Guillard, R. R. L., Lee, H.-T. (1981) Genetic variability and differentiation in the temperature niche component of the diatom Thalassiosira pseudonana. Mar. Biol. 62: 103-110

Costello, J. C., Chisholm, S. W. (1981). The influence of cell size on growth rate of Thalassiosira weissflogii. J. Plankton Res. 3: 415-419

Davis, C. O., Harrison, P. J., Dugdale, R. C. (1973), Continuous culture of marine diatoms under silicate limitation. I. Synchronized life cycle of Skeletonema costatum. J. Phycol. 9: 175-180

Denman, K. L., Powell, J. M. (1984). Effects of physical processes on the planktonic ecosystems in the coastal ocean. Oceanogr. mar. Biol. Ann. Rev. 22: 125-168

Drebes, G. (1966). On the life history of the marine plankton diatom Stephanopyxis palmeriana (Grav.) Grünow. Helgoländer wiss. Meeresunters. 13; 101-114

Drebes, G. (1977). Sexuality. In: Werner, D. (ed.) The biology of diatoms. Univ. California Press, Berkeley, p. 250-283

Gallagher, J. C. (1983). Cell enlargement in Skeletonema costatum. J. Phycol. 19: 539-542

Gross, F. (1937). Notes on the culture of some marine plankton organisms. J. mar. biol. Ass. U.K. 34:229-231

Harrison, P. J., Waters, R. E., Taylor F. J. R. (1980). A broad spectrum artificial seawater medium for coastal and open ocean phytoplankton. J. Phycol. 16: 28-35

Hutchinson, G. E. (1961). Paradox of the plankton. Am. Nat. 95: $137-145$

Jackson, G. A. (1990). The formation of marine algal flocs by physical coagulation processes. Deep Sea Res. 37: $1197-1211$

Kierstead, H., Slobodkin, L. B. (1953). The size of water masses containing plankton blooms. J. mar. Res. 12: 141-147

Krawiec, R. W. (1982). Autecology and clonal variability of the marine centric diatom Thalassiosira rotula (Bacillariophyceae) in response to light, temperature and salinity. Mar. Biol. 69: 79-89

Lewis, W. M. Jr (1983). Interruption of synthesis as a cost of sex in small organisms. Am. Nat. 121: 825-834

Lewis, W. M. Jr (1984). The diatom sex clock and its evolutionary significance. Am. Nat. 123: 73-80

Lewis, W. M. Jr (1987). The cost of sex. In: Stearns, S.C. (ed.) The evolution of sex and its consequences. Birkhauser Verlag, Basel, p. 33-57

Machlis, L. (1972). The coming of age of sex hormones in plants. Mycologia 54: 235-247

Pingree, R. D., Holligan, P. M., Mardell, G. T (1978). The effect of vertical stability on phytoplankton distribution. Deep Sea Res. 25: 1011-1028

Roelofs, A. K. (1983). The distribution of diatoms in the surface sediments of British Columbia, Canada. Ph.D. thesis, Univ. of British Columbia, Vancouver 
Round, F. E. (1972). The problem of cell size during diatom cell division. Nova Hedwegia 23: 291-304

Sandgren, C. D. (1981). Characteristics of sexual and asexual resting cyst (statospore) formation in Dinobryon cylindricum. J. Phycol. 17: 199-210

Smayda, T. J., Boleyn, B. J. (1966). Experimental observations on the flotation of marine diatoms II. Skeletonema costatum and Rhizosolenia setigera. Limnol. Oceanogr. 11. $18-34$

Starr, R. C, Jaenicke, L. (1974). Purification of the hormone initiating sexual morphogenesis in Volvox carteri $\mathrm{f}$. nagariensis Iyengar. Proc. natn Acad. Sci. U.S.A. 71: $1050-1054$

Stearns, S. C. (1987). Why sex evolved and the difference it makes. In: Stearns, S.C. (ed.) The evolution of sex and its consequences. Birkhauser Verlag, Basel, p. 15-27

Steele, J. H. (1974). Spatial heterogeniety and population stability. Nature 248: 83

Therriault, J.-C., Platt, T. (1981). Environmental control of phytoplankton patchiness. Can. J. Fish. Aquat. Sci. 38: $638-641$

This article was submitted to the editor
Utermöhl, H. (1958). Zur Vervollkommnung der quantitätiven Phytoplankton-Methodik. Mitt. Inst. Ver. theor angew. Limnol. 9: 1-38

Villareal, T A. (1988). Positive buoyancy in the oceanic diatom Rhizosolenia debayana H. Pergallo. Deep Sea Res. 35: $1037-1045$

Waite, A. M., Thompson, P. A., Harrison, P. J. (1992). Does energy control the sinking rates of marine diatoms? Limnol. Oceanogr. 37: 468-477

Williams, G. C. (1975). Sex and evolution. In: Monographs in population biology. Princeton Univ. Press, Princeton

Wood. A. M. (1988). Molecular biology, single cell analysis and quantitative genetics: new evolutionary genetic approaches in phytoplankton ecology. In: Yentsch, C. M., Mague, F., Horan, P. K. (eds.) Immunochemical approaches to estuarine, coastal, and oceanographic questions. Coastal and Estuarine Lecture Series, XXV. Springer, Berlin, p. 41-73

Woods, J. D., Barkmann, W. (1986). The response of the upper ocean to solar heating. I. The mixed layer. Q. J. meteorol. Soc. 112: $1-27$

Manuscript first received: March 31, 1992

Revised version accepted: August 14, 1992 